\title{
Pewarisan Karakter Hasil dan Komponen Hasil pada Dua Populasi Persilangan Cabai Rawit Hijau (Capsicum annuum L.)
}

\author{
Inheritance of Yield and Yield Component Characters on \\ Two Mating Populations of Birds Chili (Capsicum annuum L.)
}

\author{
Tiara Yudilastari' ${ }^{1}$, Muhamad Syukur ${ }^{2 *}$, dan Sobir ${ }^{2}$ \\ ${ }^{1}$ Program Studi Pemuliaan dan Bioteknologi Tanaman, Sekolah Pascasarjana, Institut Pertanian Bogor \\ ${ }^{2}$ Departemen Agronomi dan Hortikultura, Fakultas Pertanian, Institut Pertanian Bogor \\ (Bogor Agricultural University), Jl. Meranti, Kampus IPB Darmaga, Bogor 16680, Indonesia
}

Diterima 22 Mei 2018/Disetujui 8 Oktober 2018

\begin{abstract}
Genetic information plays an important role in plant selection. This research was aimed to obtain genetic information on pattern inheritance of yield and yield component characters of two crosses population of birds chili. The research used biparental mating design consisted of 40 plants of parents population (P1 and P2), 40 plants of first generation (F1) and reciprocal (F1R) populations, 100 plants of backcross populations (BCP1 and BCP2), and 300 plants of second generation population (F2). Scaling test and joint scaling test indicated the presence of gene interaction (epistasis) in two crosses population. Estimates gene effect also showed that fruit weight character in crosses population of IPB C145 x IPB C174 was controlled by duplication epistasis, while yield per plant character in crosses population of IPB C145 XIPB C291 was controlled by complementary epistasis. All characters of both crosses populations had high broad sense heritability, but the characters in crosses population of IPB C145 XIPB C174 had medium to high narrow sense heritability, while the characters in crosses population of IPB C145 XIPB C291 had low to medium narrow sense heritability. Genetic difference between parents seemed to affect gene action of a character, in which yield per plant, number of fruits per plant, fruit weight, and fruit length characters in crosses population of IPB C145 x IPB C291 with small genetic difference were more controlled by the action of non additive gene than crosses population of IPB C145 x IPB C291 with large genetic difference.
\end{abstract}

Keywords: epistasis, gene action, genetic difference, heritability, yield

\section{ABSTRAK}

Informasi genetik memiliki peranan penting dalam kegiatan seleksi suatu tanaman. Penelitian ini bertujuan untuk memperoleh informasi genetik mengenai pola pewarisan karakter hasil dan komponen hasil pada dua populasi persilangan cabai rawit. Penelitian menggunakan rancangan persilangan biparental yang terdiri dari populasi tetua (P1 dan P2) sebanyak 40 tanaman, populasi turunan pertama (F1) dan resiprokalnya (F1R) sebanyak 40 tanaman, populasi silang balik (BCP1 dan BCP2) sebanyak 100 tanaman, serta populasi turunan kedua (F2) sebanyak 300 tanaman. Uji skala individu maupun gabungan mengindikasikan adanya interaksi gen (epistasis) pada semua karakter kedua populasi persilangan. Perkiraan efek gen menunjukkan pula karakter bobot per buah pada populasi persilangan IPB C145 x IPB C174 dikendalikan oleh epistasis duplikat, sedangkan karakter bobot buah per tanaman pada populasi persilangan IPB C145 x IPB C291 dikendalikan oleh epistasis komplementer. Semua karakter pada kedua populasi persilangan memiliki nilai heritabilitas arti luas tinggi, namun karakter-karakter pada populasi persilangan IPB C145 x IPB C174 memiliki nilai heritabilitas arti sempit sedang sampai tinggi, sedangkan karakter-karakter pada populasi persilangan IPB C145 x IPB C291 memiliki nilai heritabilitas arti sempit rendah sampai sedang. Perbedaan genetik diantara tetua diduga mempengaruhi aksi gen suatu karakter, dimana karakter bobot buah per tanaman, jumlah buah per tanaman, bobot per buah, dan panjang buah pada populasi persilangan IPB C145 x IPB C291 dengan perbedaan genetik kecil lebih banyak dikendalikan oleh aksi gen non aditif dibandingkan dengan populasi persilangan IPB C145 x IPB C174 dengan perbedaan genetik besar.

Kata kunci: aksi gen, epistasis, hasil, heritabilitas, perbedaan genetik

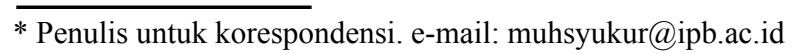




\section{PENDAHULUAN}

Cabai rawit hijau (Capsicum annuum L.) merupakan salah satu spesies yang banyak dibudidayakan dan dikonsumsi oleh masyarakat. Konsumsi masyarakat Indonesia terhadap cabai rawit memiliki rata-rata laju pertumbuhan sebesar 2.73\% per tahun (Kementerian Pertanian, 2016). Oleh karena itu, pemenuhan kebutuhan konsumsi masyarakat ini harus diiringi dengan peningkatan hasil. Peningkatan hasil dapat diperoleh melalui penggunaan varietas unggul cabai rawit yang memiliki daya hasil lebih tinggi dengan serangkaian program pemuliaan tanaman yang tepat.

Program pemuliaan tanaman diawali dengan mendapatkan keragaman genetik. Persilangan antar tetua berbeda merupakan salah satu cara mendapatkan keragaman genetik dalam membentuk suatu kombinasi persilangan. Karakter hasil dan komponen hasil termasuk dalam karakter kuantitatif yang dikendalikan oleh banyak gen dengan pengaruh kecil dan pengaruh lingkungan besar (Sleper dan Poehlman, 2006). Hal ini menjadikan pewarisan karakter hasil dan komponen hasil ini perlu dipelajari untuk mengetahui informasi genetik pada suatu tanaman. Informasi genetik ini dapat digunakan sebagai pedoman dalam menentukan metode seleksi yang tepat, sehingga seleksi yang dilakukan menjadi lebih efektif dan efisien.

Rancangan persilangan biparental dan analisis ratarata generasi merupakan salah satu pendekatan yang dapat digunakan untuk memperoleh informasi genetik seperti komponen ragam, heritabilitas, dan aksi gen. Analisis ratarata generasi ini telah banyak digunakan untuk mengetahui tipe dan besaran aksi gen yang terlibat pada pewarisan karakter cabai (Arif et al., 2012; Dhall dan Hundal, 2010; Hasanuzzaman dan Golam, 2011; Navhale et al., 2014; Patel dan Patel, 2013; Patil et al., 2012; Santos et al., 2014). Informasi mengenai aksi gen dan pendugaan heritabilitas merupakan hal penting bagi pemulia dalam rangka perbaikan karakter hasil dan komponen hasil (Sood dan Kumar, 2011). Suatu karakter pada tanaman dapat dikendalikan oleh aksi gen aditif dan non aditif yang terdiri dari aksi gen dominan dan epistasis. Karakter yang dipengaruhi aksi gen aditif menunjukkan bahwa karakter tersebut dapat diwariskan kepada turunannya dan seleksi dapat dilakukan pada generasi awal. Heritabilitas juga digunakan untuk menentukan sejauh mana suatu karakter dapat diwariskan dari tetua kepada turunannya. Melalui informasi heritabilitas, memungkinkan pemulia dalam menentukan sejauh mana intensitas seleksi yang dilakukan untuk memisahkan pengaruh lingkungan terhadap fenotipe suatu tanaman (Zehra et al., 2017). Yunandra et al. (2017) melaporkan bahwa karakter bobot buah per tanaman pada cabai memiliki heritabilitas arti sempit sedang, sedangkan karakter jumlah buah per tanaman memiliki heritabilitas arti sempit rendah. Hal ini menunjukkan aksi gen dominan lebih berperan dalam pewarisan karakter-karakter tersebut. Penelitian ini bertujuan untuk memperoleh informasi genetik mengenai pola pewarisan karakter hasil dan komponen hasil pada dua populasi persilangan cabai rawit.

\section{BAHAN DAN METODE}

Penelitian pewarisan karakter hasil dan komponen hasil dilaksanakan pada bulan Oktober 2015 sampai dengan Februari 2016 di Kebun Percobaan Leuwikopo IPB, Bogor. Penelitian menggunakan rancangan persilangan biparental yang terdiri atas populasi tetua (P1 dan $\mathrm{P} 2)$, populasi turunan pertama $(\mathrm{F} 1)$ dan resiprokalnya (F1R), populasi silang balik (BCP1 dan BCP2), serta populasi turunan kedua (F2). Materi genetik yang digunakan adalah dua populasi biparental cabai rawit yang merupakan persilangan antara IPB C145 dan IPB C174 (populasi I) serta persilangan antara IPB C145 dan IPB C291 (populasi II). Tetua IPB C145 memiliki produksi tinggi, jumlah buah tinggi, dan ukuran buah kecil, tetua IPB C174 memiliki produksi rendah, jumlah buah rendah, dan ukuran buah besar, sedangkan tetua IPB C291 memiliki produksi tinggi, jumlah buah tinggi namun tidak sebesar tetua IPB C145, dan bobot per buah yang lebih besar dari tetua IPB C145. Tetua persilangan P1 (IPB C145) dan P2 (IPB C174 dan IPB C291) ditanam sebanyak 40 tanaman. Turunan pertama (F1 IPB C145 x IPB C174 dan F1 IPB C145 x IPB C291) dan turunan pertama resiprokal (F1R IPB C174 x IPB C145 dan F1R IPB C291 x IPB C145) masing-masing ditanam sebanyak 40 tanaman. Silang balik ke tetua betina (BCP1 IPB C145 x IPB C174 dan BCP1 IPB C145 x IPB C291) dan silang balik ke tetua jantan (BCP2 IPB C145 x IPB C174 dan BCP2 IPB C145 x IPB C291) masing-masing ditanam sebanyak 100 tanaman. Turunan kedua (F2 IPB C145 x IPB C174 dan F2 IPB C145 x IPB C291) masing-masing ditanam sebanyak 300 tanaman. Pengamatan dilakukan terhadap karakter umur panen (hari setelah tanam), bobot buah per tanaman (g per tanaman), jumlah buah per tanaman (buah), bobot per buah (g), dan panjang buah $(\mathrm{cm})$.

Analisis data yang digunakan pada penelitian ini adalah pendugaan model genetik dan heritabilitas. Pendugaan model genetik menggunakan analisis rata-rata generasi terdiri atas uji skala individu, uji skala gabungan, dan perkiraan efek gen berdasarkan pada Singh dan Chaudhary (2007). Pendugaan nilai heritabilitas terdiri atas heritabilitas arti luas dan sempit dihitung berdasarkan pada Roy (2000) dengan kriteria tinggi $\left(\mathrm{h}^{2}>50 \%\right)$, sedang $\left(20 \% \leq \mathrm{h}^{2} \leq 50 \%\right)$, dan rendah $\left(\mathrm{h}^{2}<20 \%\right)$. Heritabilitas arti luas dihitung dengan rumus:

$$
h^{2}{ }_{b s}=\frac{V F 2-1 / 3(V P 1+V P 2+V F 1)}{V F 2} \times 100 \%
$$

dimana $\mathrm{h}^{2}{ }_{\text {bs }}=$ heritabilitas arti luas, VP1 = ragam populasi $\mathrm{P} 1, \mathrm{VP} 2=$ ragam populasi $\mathrm{P} 2, \mathrm{VF} 1=$ ragam populasi $\mathrm{F} 1$, dan $\mathrm{VF} 2$ = ragam populasi F2. Heritabilitas arti sempit dihitung dengan rumus:

$$
h^{2}{ }_{n s}=\frac{2 V F 2-(V B C P 1+V B C P 2)}{V F 2} \times 100 \%
$$

dimana $\mathrm{h}^{2}{ }_{\mathrm{ns}}=$ heritabilitas arti sempit, $\mathrm{VBCP} 1=$ ragam populasi $\mathrm{BCP} 1, \mathrm{VBCP} 2$ = ragam populasi $\mathrm{BCP} 2$, dan VF2 = ragam populasi $\mathrm{F} 2$. 


\section{HASIL DAN PEMBAHASAN}

\section{Pendugaan Model Genetik Karakter dan Komponen Hasil}

Uji skala individu berdasarkan analisis rata-rata generasi yang dikemukakan oleh Singh dan Chaudhary (2007) menunjukkan bahwa karakter umur panen dan jumlah buah per tanaman pada populasi I memiliki nilai skala A, B, dan $C$ yang berbeda nyata (Tabel 1). Karakter umur panen dan jumlah buah per tanaman pada populasi II memiliki nilai skala B dan C yang berbeda nyata. Karakter bobot buah per tanaman dan bobot per buah pada populasi II memiliki nilai skala A, B, dan C yang berbeda nyata, sedangkan karakter panjang buah memiliki nilai skala A dan B yang berbeda nyata (Tabel 1). Hasil uji skala yang nyata pada salah satu atau lebih skala mengindikasikan model aditif dominan tidak sesuai untuk menjelaskan model genetik karakterkarakter yang diamati, sehingga perlu dilakukan uji skala gabungan yang melibatkan interaksi gen antar lokus.

Uji skala gabungan menunjukkan model aditif dominan dengan pengaruh interaksi aditif $\mathrm{x}$ dominan, dan interaksi dominan $\mathrm{x}$ dominan dengan lima komponen $\mathrm{m}[\mathrm{d}][\mathrm{h}][\mathrm{j}][\mathrm{l}]$ sesuai untuk karakter umur panen pada populasi I. Model aditif-dominan dengan pengaruh interaksi aditif $\mathrm{x}$ aditif, dan interaksi aditif $\mathrm{x}$ dominan dengan lima komponen $\mathrm{m}[\mathrm{d}][\mathrm{h}][\mathrm{i}][\mathrm{j}]$ sesuai untuk karakter bobot buah per tanaman, jumlah buah per tanaman, dan panjang buah pada populasi I, sedangkan model yang sesuai untuk karakter bobot per buah pada populasi ini adalah model aditif-dominan dengan pengaruh interaksi aditif $\mathrm{x}$ aditif, dan interaksi dominan $\mathrm{x}$ dominan dengan lima komponen $\mathrm{m}$ [d] [h] [i] [1]. Model aditif-dominan dengan pengaruh interaksi aditif $\mathrm{x}$ dominan, dan interaksi dominan $\mathrm{x}$ dominan dengan lima komponen $\mathrm{m}$ [d] [h] [j] [1] sesuai untuk karakter umur panen, bobot buah per tanaman, jumlah buah per tanaman, dan bobot per buah pada populasi II, sedangkan model aditif-dominan dengan pengaruh interaksi aditif $\mathrm{x}$ aditif, dan interaksi dominan $\mathrm{x}$ dominan dengan lima komponen $\mathrm{m}$ [d] [h] [i] [1] sesuai untuk panjang buah pada populasi II. (Tabel 2). Hasil uji skala gabungan ini menunjukkan karakter bobot buah per tanaman, jumlah buah per tanaman, bobot per buah, dan panjang buah pada populasi II memiliki pengaruh non aditif yang lebih besar dibandingkan pengaruh aditif, sebaliknya pengaruh aditif lebih besar dari pengaruh non aditif pada populasi I.

Perkiraan efek gen pada karakter umur panen, bobot buah per tanaman, jumlah buah per tanaman, bobot per buah, dan panjang buah kedua populasi persilangan disajikan pada Tabel 3. Mather dan Jinks (1982) menyatakan apabila nilai [h] dan [1] pada suatu karakter signifikan serta memiliki tanda yang sama disebut sebagai tipe komplementasi, sedangkan apabila nilai [h] dan [l] signifikan serta memiliki tanda yang berbeda disebut sebagai tipe duplikasi. Karakter bobot per buah pada populasi persilangan IPB C145 x IPB C174 (populasi I) dikendalikan oleh interaksi gen duplikasi, sedangkan karakter bobot buah per tanaman pada populasi persilangan IPB C145 x IPB C291 (populasi II) dikendalikan oleh interaksi gen komplementasi. Beberapa penelitian menunjukkan hasil yang sama, seperti karakter bobot per buah (Arif et al., 2012; Navhale et al., 2014; Manu et al., 2014) untuk interaksi gen duplikasi, dan karakter bobot buah per tanaman (Patel dan Patel, 2013) untuk interaksi gen komplementasi.

Interaksi gen komplementasi dapat meningkatkan keragaman diantara generasi pada populasi bersegregasi (Said, 2014). Selain itu, aksi gen komplementasi juga dapat meningkatkan heterosis, sedangkan aksi gen duplikasi menyebabkan penurunan heterosis (Hasanuzzaman dan Golam, 2011). Interaksi gen duplikasi biasanya mengakibatkan tingkat keragaman terbatas, sehingga kemajuan seleksi pada suatu karakter akan menjadi terhambat (Yahaya et al., 2014). Kemunculan interaksi gen duplikasi dan komplementasi pada persilangan yang berbeda dalam satu karakter mengindikasikan karakter tersebut dikendalikan oleh aksi gen aditif dan non aditif (Patil et al., 2012). Oleh karena itu, seleksi pada karakter yang dikendalikan oleh aksi gen epistasis sebaiknya tidak dilakukan pada generasi awal melainkan generasi

Tabel 1. Uji skala individu karakter karakter hasil dan komponen hasil pada kedua populasi persilangan

\begin{tabular}{lcccc}
\hline Karakter & Populasi & A & B & C \\
\hline Umur panen & I & $6.462^{* *}$ & $12.497^{* *}$ & $15.423^{* *}$ \\
Bobot buah per tanaman & II & $-1.939 \mathrm{tn}$ & $8.582^{* *}$ & $6.197^{*}$ \\
& I & $17.175 \mathrm{tn}$ & $28.091^{*}$ & $106.039^{* *}$ \\
Jumlah buah per tanaman & II & $-145.670^{* *}$ & $-248.143^{* *}$ & $-461.228^{* *}$ \\
Bobot per buah & I & $63.671^{* *}$ & $34.980^{*}$ & $165.122^{* *}$ \\
& II & $-23.426 \mathrm{tn}$ & $-141.765^{* *}$ & $-156.511^{* *}$ \\
Panjang buah & I & $0.056 \mathrm{tn}$ & $-0.247^{*}$ & $0.458^{* *}$ \\
& II & $-0.321^{* *}$ & $-0.530^{* *}$ & $-0.707^{* *}$ \\
\hline
\end{tabular}

Keterangan: Populasi I = populasi persilangan IPB C145 x IPB C174, Populasi II = populasi persilangan IPB C145 x IPB C291, ** = berbeda nyata pada $\alpha 0.01, *$ = berbeda nyata pada $\alpha 0.05$, dan $\mathrm{tn}=$ tidak berbeda nyata pada $\alpha 0.05$ 
Tabel 2. Uji skala gabungan karakter karakter hasil dan komponen hasil pada kedua populasi persilangan

\begin{tabular}{|c|c|c|c|c|c|c|}
\hline Model genetik & Pop. & Umur panen & $\begin{array}{l}\text { Bobot buah } \\
\text { per tanaman }\end{array}$ & $\begin{array}{l}\text { Jumlah buah } \\
\text { per tanaman }\end{array}$ & Bobot per buah & Panjang buah \\
\hline \multirow[t]{2}{*}{$\mathrm{m}[\mathrm{d}]$} & I & $43.61 * *$ & $90.70 * *$ & $41.67 * *$ & $23.85 * *$ & $73.63 * *$ \\
\hline & II & $55.45^{* *}$ & $114.20 * *$ & $24.57 * *$ & $73.38 * *$ & $139.74 * *$ \\
\hline \multirow[t]{2}{*}{$\mathrm{m}[\mathrm{d}][\mathrm{h}]$} & I & $43.20 * *$ & $18.64 * *$ & $27.74 * *$ & $21.73 * *$ & $21.57 * *$ \\
\hline & II & 14.42 & $113.65^{* *}$ & $15.36^{* *}$ & $60.21 * *$ & $11.87 * *$ \\
\hline \multirow[t]{2}{*}{$\mathrm{m}[\mathrm{d}][\mathrm{h}][\mathrm{i}]$} & I & $16.94 * *$ & $0.23 \mathrm{tn}$ & $0.93 \mathrm{tn}$ & $8.74^{*}$ & $20.79 * *$ \\
\hline & II & $11.86^{* *}$ & $22.47 * *$ & $9.91 * *$ & $20.92 * *$ & $10.75^{* *}$ \\
\hline \multirow[t]{2}{*}{$\mathrm{m}[\mathrm{d}][\mathrm{h}][\mathrm{j}]$} & I & $40.46^{* *}$ & $16.41 * *$ & $27.74 * *$ & $17.76^{* *}$ & $1.08 \mathrm{tn}$ \\
\hline & II & $5.38 \mathrm{tn}$ & $112.43 * *$ & $11.07 * *$ & $60.07 * *$ & $11.81^{* *}$ \\
\hline \multirow[t]{2}{*}{$\mathrm{m}[\mathrm{d}][\mathrm{h}][\mathrm{l}]$} & I & $5.37 \mathrm{tn}$ & $4.29 \mathrm{tn}$ & $4.50 \mathrm{tn}$ & $17.94 * *$ & $20.48 * *$ \\
\hline & II & $11.37 * *$ & $10.29 * *$ & $7.12 *$ & $4.48 \mathrm{tn}$ & $6.05 *$ \\
\hline \multirow[t]{2}{*}{$\mathrm{m}[\mathrm{d}][\mathrm{h}][\mathrm{i}][\mathrm{j}]$} & I & $13.60 * *$ & 0.10 tn & $0.24 \mathrm{tn}$ & $7.82 \mathrm{tn}$ & $0.63 \mathrm{tn}$ \\
\hline & II & $1.23 \mathrm{tn}$ & $17.75^{* *}$ & $3.66 \mathrm{tn}$ & $19.93 * *$ & $10.73 * *$ \\
\hline \multirow[t]{2}{*}{$\mathrm{m}[\mathrm{d}][\mathrm{h}][\mathrm{i}][\mathrm{l}]$} & I & $4.60 *$ & $0.21 \mathrm{tn}$ & $0.86 \mathrm{tn}$ & $3.56 \mathrm{tn}$ & $20.48 * *$ \\
\hline & II & $11.37 * *$ & $7.20 * *$ & $7.07 * *$ & $3.68 \mathrm{tn}$ & $0.01 \mathrm{tn}$ \\
\hline \multirow[t]{2}{*}{$\mathrm{m}[\mathrm{d}][\mathrm{h}][\mathrm{j}][\mathrm{l}]$} & I & $1.04 \mathrm{tn}$ & $4.26^{*}$ & $2.99 \mathrm{tn}$ & $16.30 * *$ & $1.06 \mathrm{tn}$ \\
\hline & II & $0.02 \mathrm{tn}$ & $2.65 \mathrm{tn}$ & $0.03 \mathrm{tn}$ & $1.36 \mathrm{tn}$ & $6.04 *$ \\
\hline
\end{tabular}

Keterangan: Pop. I = populasi persilangan IPB C145 x IPB C174; Pop. II = populasi persilangan IPB C145 x IPB C291; $\mathrm{m}=$ nilai tengah; $\mathrm{d}=$ pengaruh aditif; $\mathrm{h}=$ pengaruh dominan; $\mathrm{i}=$ pengaruh interaksi aditif $\mathrm{x}$ aditif; $\mathrm{j}=$ pengaruh interaksi aditif $\mathrm{x}$ dominan; $1=$ pengaruh interaksi dominan $\mathrm{x}$ dominan; $* *=$ berbeda nyata pada $\alpha 0.01 ; *=$ berbeda nyata pada $\alpha 0.05 ;$ tn $=$ tidak berbeda nyata pada $\alpha 0.05$ berdasarkan uji $\chi^{2}$

Tabel 3. Perkiraan efek gen karakter hasil dan komponen hasil pada kedua populasi persilangan

\begin{tabular}{|c|c|c|c|c|c|}
\hline Komponen & $\begin{array}{l}\text { Umur } \\
\text { panen }\end{array}$ & $\begin{array}{c}\text { Bobot buah per } \\
\text { tanaman }\end{array}$ & $\begin{array}{c}\text { Jumlah buah per } \\
\text { tanaman }\end{array}$ & Bobot per buah & Panjang buah \\
\hline \multicolumn{6}{|c|}{ Populasi persilangan IPB C145 x IPB C174 (Populasi I) } \\
\hline $\mathrm{m}$ & $68.09 * *$ & $96.22 * *$ & $122.86^{* *}$ & $1.50 * *$ & $4.72 * *$ \\
\hline$[\mathrm{d}]$ & $-1.22 \mathrm{tn}$ & $80.39^{* *}$ & $105.56^{* *}$ & $-0.20 * *$ & $-0.61 \mathrm{tn}$ \\
\hline$[\mathrm{h}]$ & $0.32 \mathrm{tn}$ & $-129.40 * *$ & $-113.80 * *$ & $-0.79 * *$ & $0.21 \mathrm{tn}$ \\
\hline [i] & $3.54 \mathrm{tn}$ & $-60.77^{*}$ & $-66.47^{*}$ & $-0.65 * *$ & $-0.29 \mathrm{tn}$ \\
\hline$[\mathrm{j}]$ & $-3.02 *$ & $-5.46 \mathrm{tn}$ & $14.35 \mathrm{tn}$ & $0.15^{*}$ & $0.50 * *$ \\
\hline$[1]$ & $-22.50 * *$ & $15.51 \mathrm{tn}$ & $-32.18 \mathrm{tn}$ & $0.84 * *$ & $0.41 \mathrm{tn}$ \\
\hline Efek Gen & - & - & - & Duplikasi & - \\
\hline \multicolumn{6}{|c|}{ Populasi persilangan IPB C145 x IPB C291 (Populasi II) } \\
\hline $\mathrm{m}$ & $68.52 * *$ & $80.62 * *$ & $161.55^{* *}$ & $1.13 * *$ & $4.03 * *$ \\
\hline [d] & $-7.60 * *$ & $73.14^{* *}$ & $85.30 * *$ & $0.00 \mathrm{tn}$ & 0.10 tn \\
\hline [h] & $-5.57 \mathrm{tn}$ & $123.30 * *$ & $51.97 \mathrm{tn}$ & $0.04 \mathrm{tn}$ & $0.25 \mathrm{tn}$ \\
\hline [i] & $0.45 \mathrm{tn}$ & $67.42 \mathrm{tn}$ & $-8.68 \mathrm{tn}$ & $-0.14 \mathrm{tn}$ & $-0.57 * *$ \\
\hline [j] & $-5.26^{* *}$ & $51.24 * *$ & $59.17 * *$ & $0.11^{*}$ & $0.01 \mathrm{tn}$ \\
\hline$[1]$ & $-7.09 \mathrm{tn}$ & $326.40 * *$ & $173.87^{*}$ & $0.99 * *$ & $1.35^{* *}$ \\
\hline Efek Gen & - & Komplementasi & - & - & - \\
\hline
\end{tabular}

Keterangan: $\mathrm{m}=$ nilai tengah; $\mathrm{d}=$ pengaruh aditif; $\mathrm{h}=$ pengaruh dominan; $\mathrm{i}=$ pengaruh interaksi aditif $\mathrm{x}$ aditif; $\mathrm{j}=$ pengaruh interaksi aditif $\mathrm{x}$ dominan; 1 = pengaruh interaksi dominan $\mathrm{x}$ dominan; $* *=$ berbeda nyata pada $\alpha 0.01$; $*$ = berbeda nyata pada $\alpha 0.05 ;$ tn $=$ tidak berbeda nyata pada $\alpha 0.05$ berdasarkan uji t 
selanjutnya saat efek dominan sudah berkurang. Metode seleksi berulang resiprokal disarankan untuk peningkatan karakter yang dikendalikan oleh aksi gen aditif dan non aditif yang terlibat dalam ekspresi suatu karakter (Yahaya et al., 2014). Metode seleksi bulk yang dimodifikasi dapat menjadi metode yang direkomendasikan untuk karakter dengan aksi gen epistasis, dimana seleksi dilakukan setelah homozigositas lokus maksimal. Selain itu, kehadiran interaksi gen komplementasi dan meratanya besaran efek gen non aditif tinggi yang ditemukan pada sebagian besar karakter mengindikasikan pemanfaatan heterosis juga dapat dikembangkan dalam pemuliaan cabai untuk memperoleh daya hasil tinggi (Adarsh dan Kumari, 2015).

\section{Heritabilitas pada Karakter dan Komponen Hasil}

Heritabilitas merupakan salah satu parameter genetik yang dapat digunakan untuk mengetahui peranan genetik dalam pewarisan suatu karakter dari tetua kepada turunannya. Karakter hasil dan komponen hasil pada kedua populasi persilangan memiliki nilai heritabilitas arti luas yang tinggi (Tabel 4). Hal ini mengindikasikan peranan faktor genetik lebih besar dibandingkan faktor lingkungan dalam mempengaruhi penampilan suatu tanaman dan sifat-sifat tersebut dapat terwariskan pula pada generasi selanjutnya. Beberapa penelitian juga menunjukkan karakter hasil dan komponen hasil memiliki nilai heritabilitas arti luas tinggi, yaitu karakter bobot buah per tanaman (Adday, 2016), jumlah buah per tanaman (Hastuti et al., 2016), bobot per buah (Singh et al., 2017), umur panen, dan panjang buah (Zehra et al., 2017).

Karakter-karakter populasi persilangan IPB C145 x IPB C174 (populasi I) memiliki nilai heritabilitas arti sempit yang berada pada kisaran sedang sampai tinggi, sedangkan karakter-karakter populasi persilangan IPB C145 x IPB C291 (populasi II) memiliki nilai heritabilitas arti sempit yang berada pada kisaran rendah sampai sedang. Nilai heritabilitas arti sempit tinggi pada populasi I terdapat pada karakter bobot buah per tanaman, jumlah buah per tanaman, dan panjang buah, sedangkan nilai heritabilitas arti sempit sedang terdapat pada karakter umur panen dan bobot per buah. Karakter umur panen, bobot buah per tanaman, jumlah buah per tanaman, dan panjang buah pada populasi II memiliki nilai heritabilitas arti sempit yang sedang, sedangkan karakter bobot per buah memiliki nilai heritabilitas arti sempit rendah (Tabel 4). Beberapa penelitian menunjukkan hasil yang sama, yaitu karakter bobot buah per tanaman (Syukur et al., 2010) dan panjang buah (Hasanuzzaman et al., 2012) untuk heritabilitas arti sempit tinggi, karakter jumlah buah per tanaman (Nsabiyera et al., 2013), umur panen (Yunandra et al., 2017), dan bobot per buah (Arif et al., 2012) untuk heritabilitas arti sempit sedang. Nilai heritabilitas dalam arti sempit yang berada pada kisaran rendah hingga sedang pada kedua populasi persilangan diduga disebabkan oleh pengaruh gen dominan kontribusinya lebih besar dibandingkan pengaruh gen aditif dalam genetik suatu tanaman. Hasil pendugaan nilai heritabilitas ini sesuai pula dengan uji skala gabungan

Tabel 4. Komponen ragam dan heritabilitas karakter hasil dan komponen hasil pada kedua populasi persilangan

\begin{tabular}{lcrrrrr}
\hline Komponen & Populasi & Umur panen & $\begin{array}{c}\text { Bobot buah per } \\
\text { tanaman }\end{array}$ & $\begin{array}{c}\text { Jumlah buah } \\
\text { per tanaman }\end{array}$ & Bobot per buah & Panjang buah \\
\hline VP1 & I & 12.05 & $2,625.13$ & $3,327.18$ & 0.02 & 0.04 \\
VP2 & II & 12.05 & $2,625.13$ & $3,327.18$ & 0.02 & 0.04 \\
& I & 14.82 & 131.27 & 82.26 & 0.13 & 0.15 \\
VF1 & II & 36.23 & $5,772.99$ & $7,528.64$ & 0.04 & 0.09 \\
& I & 24.17 & 660.14 & $1,340.09$ & 0.05 & 0.27 \\
VBCP1 & II & 13.59 & $3,122.51$ & $3,130.91$ & 0.03 & 0.10 \\
& I & 70.21 & $6,212.12$ & $9,567.75$ & 0.13 & 0.31 \\
VBCP2 & II & 72.37 & $9,464.83$ & $11,910.81$ & 0.07 & 0.29 \\
VF2 & I & 65.28 & $2,060.58$ & $3,447.54$ & 0.13 & 0.47 \\
& II & 72.63 & $9,396.83$ & $11,160.56$ & 0.08 & 0.24 \\
h'bs & I & 82.49 & $7,060.34$ & $10,592.92$ & 0.16 & 0.56 \\
& II & 85.13 & $10,738.18$ & $13,476.27$ & 0.08 & 0.31 \\
h $^{2}$ ns & I & 79.37 & 83.87 & 85.05 & 55.89 & 72.21 \\
& II & 75.78 & 64.24 & 65.40 & 62.02 & 75.65
\end{tabular}

Keterangan: I = populasi persilangan IPB C145 x IPB C174; II = populasi persilangan IPB C145 x IPB C291; VP1 = ragam P1; VP2 = ragam $\mathrm{P} 2 ; \mathrm{VF} 1$ = ragam $\mathrm{F} 1 ; \mathrm{VBCP} 1=$ ragam $\mathrm{BCP} 1 ; \mathrm{VBCP} 2=\operatorname{ragam} \mathrm{BCP} 2 ; \mathrm{VF} 2=$ ragam $\mathrm{F} 2 ; \mathrm{h}^{2} \mathrm{bs}=$ heritabilitas arti luas; $\mathrm{h}^{2} \mathrm{~ns}=$ heritabilitas arti sempit 
dimana pengaruh gen non aditif lebih besar dibandingkan pengaruh aditifpada karakter-karakter populasi II, sebaliknya pengaruh aditif lebih besar dibandingkan pengaruh non aditif pada karakter-karakter populasi I.

Perbedaan genetik diantara tetua diduga mempengaruhi aksi gen suatu karakter, dimana karakter bobot buah per tanaman, jumlah buah per tanaman, bobot per buah, dan panjang buah pada populasi II dengan perbedaan genetik kecil lebih banyak dikendalikan oleh aksi gen non aditif dibandingkan dengan populasi I dengan perbedaan genetik besar. Menurut Nsabiyera et al. (2013) karakter yang dikendalikan oleh aksi gen aditif dapat dilakukan seleksi pada generasi awal dengan menggunakan seleksi backcross, pemuliaan silsilah (pedigree) dengan seleksi berulang (recurrent selection), dan seleksi massa. Pemuliaan heterosis dan silsilah (pedigree) dengan metode seleksi yang sederhana dapat digunakan untuk peningkatan karakter-karakter yang dikendalikan oleh aksi gen aditif dan non aditif dalam program pemuliaan. Janaki et al. (2015) menyatakan pula karakter yang dikendalikan oleh aksi gen aditif dan non aditif sebaiknya menggunakan seleksi massa, seleksi silsilah, atau prosedur seleksi lain yang dimodifikasi untuk mengeksploitasi efek gen aditif.

\section{KESIMPULAN}

Karakter hasil dan komponen hasil pada kedua populasi persilangan dikendalikan oleh aksi gen aditif maupun non aditif yang terdiri atas dominan dan epistasis. Karakter bobot per buah pada populasi persilangan IPB C145 x IPB C174 dikendalikan oleh interaksi gen duplikasi, sedangkan karakter bobot buah per tanaman pada populasi persilangan IPB C145 x IPB C291 dikendalikan oleh interaksi gen komplementasi. Semua karakter pada kedua populasi persilangan memiliki nilai heritabilitas arti luas tinggi, namun karakter-karakter pada populasi persilangan IPB C145 x IPB C174 memiliki nilai heritabilitas arti sempit yang sedang sampai tinggi, sedangkan karakter-karakter pada populasi persilangan IPB C145 x IPB C291 memiliki nilai heritabilitas arti sempit rendah sampai sedang. Karakter bobot buah per tanaman, jumlah buah per tanaman, bobot per buah, dan panjang buah pada populasi persilangan IPB C145 x IPB C291 dengan perbedaan genetik kecil lebih banyak dikendalikan oleh aksi gen non aditif dibandingkan dengan populasi persilangan IPB C145 x IPB C174 dengan perbedaan genetik besar.

\section{UCAPAN TERIMA KASIH}

Terima kasih disampaikan kepada Kementerian Riset, Teknologi, dan Pendidikan Tinggi yang telah membiayai penelitian ini melalui Hibah Kompetensi tahun 2014-2015 atas nama Muhamad Syukur.

\section{DAFTAR PUSTAKA}

Adarsh, M.N., P. Kumari. 2015. Combining ability and gene action studies for important horticultural traits in chilli (Capsicum annuum L.). Int. J. Farm. Sci. 5:251-262.

Adday, H.A. 2016. Estimation of heterosis combining ability and some genetic parameters in sweet pepper. J. Genet. Environ. Resour. Conserv. 4:32-38.

Arif, A.B., S. Sujiprihati, M. Syukur. 2012. Pendugaan parameter genetik pada beberapa karakter kuantitatif pada persilangan antara cabai besar dengan cabai keriting (Capsicum annuum L.). J. Agron. Indonesia 40:119-124.

Dhall, R.K., J.S. Hundal. 2010. Genetics of fruit size in chilli. Indian J. Hort. 67:117-121.

Hasanuzzaman, M., F. Golam. 2011. Gene actions in yield and yield contributing traits of chilli (Capsicum annuum L.). Aust. J. Crop Sci. 5:1868-1875.

Hasanuzzaman, M., M.A Hakim, J. Fersdous, M.M. Islam, L. Rahman. 2012. Combining ability and heritability analysis for yield and yield contributing characters in chilli (Capsicum annuum) landraces. Plant Omics J. 5:337-344.

Hastuti, N.M.D., I. Yulianah, D. Saptadi. 2016. Heritabilitas dan kemajuan genetik harapan 7 famili populasi F3 hasil persilangan cabai besar (Capsicum annuum L.) TW 2 x PBC 473. J. Produksi Tanaman 4:63-72.

Janaki, M., L.N. Naidu, C.V. Ramana, P. Rao. 2015. Assessment of genetic variability, heritability, and genetic advance for quantitative traits in chilli (Capsicum annuum L.). The Bioscan 10:729-733.

Kementerian Pertanian. 2016. Outlook Komoditas Pertanian Sub Sektor Hortikultura (Cabai). Pusat Data dan Sistem Informasi Pertanian Kementerian Pertanian, Jakarta.

Manu, D.G., B.V. Tembhurne, B. Kisan, D.S. Aswathnarayana, J.R. Diwan. 2014. Inheritance of fusarium wilt and qualitative and quantitative characters in Chilli (Capsicum annuum L.). J. Agric. Env. Sci. 3:433-444.

Mather, S.K., J.L. Jink. 1982. Biometrical Genetics: The Study of Continuous Variation. Edisi ketiga. Chapman and Hall, New York. 
Navhale, V.C., V.V. Dalvi, M.M. Wakode, S.G. Bhave, J.P. Devmore. 2014. Gene action of yield and yield contributing characters in chilli (Capsicum annuum L.). Electron. J. Plant Breed. 5:729-734.

Nsabiyera, V., M.O. Ssemakula, P. Sseruwagi, C. Ojiewo, P. Gibson. 2013. Combining ability for field resistence to disease, fruit yield and yield factors among hot pepper (Capsicum annuum L.) genotypes in Uganda. Int. J. Plant Breed. 7:12-21.

Patel, R.K., J.A. Patel. 2013. Genetic analysis for green fruit yield and its components in chilli (Capsicum annuum var. longum (D.C.) Sendt.). Madras Agric. J. 100:283-286.

Patil, B.T., M.N. Bhalekar, K.G. Shinde, S.S. Dhumal. 2012. Studies on gene action and gene effects for fruit and seed attributes in chilli (Capsicum annuum L.). Prog. Agric. 12:209-213.

Roy, D. 2000. Plant Breeding, Analysis and Exploitation of Variation. Narosa Publishing House, New Delhi, INA.

Said,A.A. 2014. Generation mean analysis in wheat (Triticum aestivum L.) under drought stress conditions. Ann. Agric. Sci. 59:177-184.

Santos, R.M.C., E.R. do Rego, A. Borem, M.F. Nascimento, N.F.F. Nascimento, F.L. Finger, M.M. Rego. 2014. Epistasis and inheritance of plant habit and fruit quality traits in ornamental pepper (Capsicum annuum L.). Genet. Mol. Res. 13:8867-8887.

Sleper, D.A., J.M. Poehlman. 2006. Breeding Field Crops. Edisi kelima. Blackwell Publishing, Iowa.
Singh, R.K., B.D. Chaudhary. 2007. Biometrical Methods in Quantitative Genetic Analysis. Reprinted. Kalyani Publisher, New Delhi, INA.

Singh, P., P.K. Jain, A. Sharma. 2017. Genetic variability, heritability and genetic advance in chilli (Capsicum annuum L.) genotypes. Int. J. Curr. Microbiol. App. Sci. 6:2704-2709.

Sood, S., N. Kumar. 2011. Genetic estimates of fruit yield and its component traits in bell pepper (Capsicum annuum L. var. grossum Sendt.). Sabrao J. Breed. Genet. 43:122-129.

Syukur, M., S. Sujiprihati, R. Yunianti, Undang. 2010. Diallel analysis using hayman method to study genetic parameters of yield components in pepper (Capsicum annuum L.). Hayati J. Biosci. 17:183-188.

Yahaya, A.I., S.G. Ado, M.F. Ishiyaku, I. Onu, A. Usman. 2014. Estimates of additive, dominance and epistatic variation for yield and other agronomic traits under three different conditions in cotton. Nigerian J. Crop Sci. 2:53-61.

Yunandra, M. Syukur, A. Maharijaya. 2017. Seleksi dan kemajuan seleksi karakter komponen hasil pada persilangan cabai keriting dan cabai besar. J. Agron. Indonesia 45:169-174.

Zehra, S.B., S.H. Khan, A. Ahmad, B. Afroza, K. Parveen, K. Hussain. 2017. Genetic variability, heritability and genetic advance for various quantitative and qualitative traits in chilli (Capsicum annuum L.). J. Appl. \& Nat. Sci. 9:262-273. 